\title{
A transição religiosa brasileira e o processo de difusão das filiações evangélicas no Rio de Janeiro
}

\author{
The Brazilian religious transition and the process of diffusion of evangelical \\ affiliations in Rio de Janeiro
}

\author{
José Eustáquio Diniz Alves* \\ Suzana Marta Cavenaghi** \\ Luiz Felipe Walter Barros ***
}

\section{Resumo}

O catolicismo tem sido a religião hegemônica no Brasil. Todavia, nas últimas décadas o país está passando por uma grande transformação religiosa, com queda das filiações católicas e um rápido crescimento dos evangélicos, além do aumento, em ritmo menor, de outras religiões e das pessoas que se declaram semreligião. Assim, cresce a pluralidade religiosa, embora o cristianismo continue amplamente majoritário no país. Mas no seio da religião cristã está havendo uma mudança de hegemonia entre católicos e evangélicos. Uma inovação do dogma e da prática evangélica ocorrida no século XX, nos Estados Unidos, permitiu a difusão das mensagens pentecostais e neopentecostais. O Brasil, sendo o maior país católico do mundo, ganha destaque neste processo. O estado do Rio de Janeiro é o que apresenta menor proporção de católicos e a maior diversidade religiosa no país. Sua Região Metropolitana é a aglomeração urbana mais avançada neste processo de mudança de hegemonia. Esse artigo mostra, adicionalmente, que o processo de expansão evangélica segue um padrão espacial que avança pelas principais rodovias do território fluminense tendo como foco de difusão a periferia da Região Metropolitana do Rio de Janeiro.

Palavras-chave: religião, inovação e difusão, católicos, evangélicos, Rio de Janeiro.

\begin{abstract}
Catholicism has been the hegemonic religion in Brazil. However, in recent decades the country is undergoing a major religious transformation, with a drop of Catholic affiliations and rapid growth of evangelicals, and a increase to a lesser pace, of other religions and no-religion. Hence, there is a growing religious plurality, although Christianity remains widely majority in the country. But within the Christian religion there is a change of hegemony between Catholics and evangelicals. An innovation of the dogma and the evangelical practice occurred in the twentieth century, in the United States, allowed the spread of Pentecostal and neo-Pentecostal messages. Brazil, as the largest Catholic country in the world, is highlighted in this process. The state of Rio de Janeiro features as having the smaller proportion of Catholics and the most religiously diverse in the country. Its metropolitan area is the most advanced urban agglomeration in this changing process of hegemony. This paper shows, additionally, that the process of evangelical diffusion follows a spatial pattern that goes along the main roads of the Rio de Janeiro territory having as the focus of diffusion the periphery of the metropolitan area of the State.
\end{abstract}

Keywords: religion, innovation and diffusion, catholics, evangelicals, Rio de Janeiro

\footnotetext{
Artigo recebido em 23 de agosto de 2014 e aprovado em 21 de Outubro de 2014.

* Doutor em Demografia. Professor do Instituto Brasileiro de Geografia e Estatística - IBGE. País de origem: Brasil. E-mail: jed_alves@yahoo.com.

** Doutora em Demografia. Professora do Instituto Brasileiro de Geografia e Estatística - IBGE. País de origem: Brasil. E-mail: suzana_cavenaghi@uol.com.br.

*** Mestre em Estudos Populacionais e Pesquisas Sociais. É analista da Gerência Técnica do Censo Demográfico (GTD) da Diretoria de Pesquisa do IBGE. País de origem: Brasil. E-mail: Ifelipewb@gmail.com.
} 


\section{Introdução}

O Brasil vem passando por diversas transformações econômicas, sociais e culturais de grande fôlego. Sem romper totalmente com o passado, na segunda metade do século XX o país acelerou o processo de mudança de uma economia primário-exportadora, sustentada em uma base agrária e rural, para uma economia urbana, sustentada em uma base industrial e de serviços. Paralelamente, houve uma transição demográfica com a passagem de altas para baixas taxas de mortalidade e natalidade, que foi acompanhada por uma transição epidemiológica com modificação das causas de óbitos. Concomitantemente, houve diversificação dos padrões de família e nas formas de convivência dos arranjos domiciliares. Tudo isto reunido possibilitou a transição de uma sociedade tradicional, patriarcal e com baixa mobilidade social para uma sociedade de traços pós-modernos, póspatriarcal, democrática e marcada pelo enfraquecimento da autoridade tradicional, por uma forte mobilidade espacial e social, por mudanças significativas nas relações de gênero e geração, com maior empoderamento das mulheres e crescente autonomia dos indivíduos (ALVES ; CORREA, 2009).

Transições sociais e culturais abrem espaço para transformações no mundo religioso. As religiões internalizadas, na concepção de Weber (1967), têm a característica de oferecerem alternativas de orientação de vida para seus filiados, o que é essencial em um mundo em transformação. Tanto as confissões evangélicas quanto as católicas, com maior ou menor ênfase, possuem essas características. Para Pierucci e Prandi:

Não é a religião enquanto conservação e permanência que deve interessar à sociologia, mas sim a religião em mudança, a religião como possibilidade de ruptura e inovação, a mudança religiosa e, portanto, a mudança cultural. (PIERUCCI; PRANDI, 1996, p.9).

Os autores, citando Cândido Procópio Camargo (1971), mostram a importância da cisão no seio das denominações cristãs e do processo “ no qual o 
catolicismo tradicional cede terreno, no Brasil urbano principalmente mas também no rural, a distintas modalidades de catolicismo internalizado" (PIERUCCI; PRANDI, 1996, p. 9).

Todavia, nos anos de 1970, ainda não estava claro o processo de expansão das confissões evangélicas e o processo de disputa de hegemonia dentro do campo cristão. O Brasil é um campo importante desta disputa.

O cristianismo (católico + evangélico + ortodoxo) é a maior religião do mundo, embora a proporção global de cristãos tenha diminuído ligeiramente de 35\% para 32\% da população total entre 1910 e 2010. Estudo do Pew Research Center's Forum on Religion \& Public Life, estimou, para 2010, o número de 5,8 bilhões de pessoas (84\%) com afiliação religiosa no globo e 1,1 bilhão de pessoas (16\%) sem religião. O estudo foi feito em 232 países e territórios, encontrando em 2010, em termos globais, 2,2 bilhões de cristãos (32\% da população mundial), 1,6 bilhão de muçulmanos (23\%), 1 bilhão de hindus (15\%), cerca de 500 milhões de budistas (7\%) e 14 milhões de judeus (o,2\%). Além disso, mais de 400 milhões de pessoas (6\%) praticavam religiões tradicionais, incluindo as religiões tradicionais africanas, religiões populares chinesas, religiões nativas americanas e religiões aborígines australianas. Além disto, o estudo estimou 58 milhões de pessoas pouco menos de $1 \%$ da população mundial - pertencendo a outras religiões, incluindo a fé Baha'i, jainismo, sikhismo, o xintoísmo, o taoísmo, o Tenrikyo, Wicca e zoroastrismo (PEW, 2012).

Segundo estudo anterior do mesmo centro de pesquisa, denominado "A Report on the Size and Distribution of the World's Christian Population" (PEW, 2011), ocorreu uma grande mudança geográfica dentro da religião cristã, nos últimos 100 anos, acompanhando, em parte, as mudanças demográficas globais. Em 1910, 66,3\% dos cristãos estavam na Europa, 27,1\% nas Américas, 4,5\% na Ásica-Pacífico e 1,4\% na África Subsaariana. Em 2010, as proporções passaram para 25,9\% na Europa, 36,8\% nas Américas, 23,6\% na África Subsaariana e 13,1\% na Ásia - Pacífico. Em 1910, o "Norte Global” (países ricos ou desenvolvidos) 
concentrava 82,2\% das filiações cristãs do mundo, enquanto o "Sul Global” (paises pobres ou em desenvolvimento) continha apenas 17,8\% das filiações. Já em 2010, o "Norte Global" abarcava somente 39,2\%, enquanto o "Sul Global” concentrava 60,8\% das filiações cristãs do mundo.

O Brasil concentra a segunda maior população cristã do globo (atrás apenas dos Estados Unidos), constituindo-se no maior país católico do mundo. A igreja católica romana chegou ao Brasil junto com a frota de Pedro Alvarez Cabral. A primeira missa foi celebrada por Frei Henrique Coimbra, no domingo de Páscoa, dia 26 de abril de 1500.

Não custa lembrar que foi em meio à expansão católica para a América Latina que surgiu em alguns países não mediterrâneos da Europa, o movimento de contestação da hegemonia da Santa Sé. A Reforma Protestante, do início do século XVI, questionou diversos pontos da doutrina da Igreja Católica Romana e se difundiu em países em que a nobreza e as forças econômicas nacionais protestavam contra a concentração das riquezas da igreja romana e contra o poderio econômico da Península Ibérica, que se enriquecia com o processo de espoliação das Américas. Mas Portugal e Espanha conseguiram manter o avanço dos protestantes em suas colônias e em todo o território da América Latina.

Contudo, os protestantes avançaram na Europa e conseguiram formar uma forte hegemonia na América do Norte. No início do século XX houve o surgimento do movimento pentecostal nos Estados Unidos. Nos últimos 100 anos os evangélicos tradicionais e, em especial, os pentecostais avançaram para os países do "Sul Global". O avanço na América Latina teve pouco sucesso até os anos de 1970. Mas uma série de transformações sociais e demográficas na sociedade e uma diversificação do movimento pentecostal abriu espaço para o avanço dos evangélicos em detrimento das filiações católicas. 
No Brasil, o processo de mudança de hegemonia religiosa ganhou impulso depois de 1980, sendo que as filiações católicas caíram de 89\% em 1980 para 64,6\% em 2010, devendo representar menos de 50\% da população brasileira até 2030 (ALVES; BARROS; CAVENAGHI, 2012; COUTINHO; GOLGHER, 2014). O Estado do Rio de Janeiro está na liderança da mudança religiosa e é a Unidade da Federação com maior diversidade religiosa e menor proporção de católicos do país (45,8\% em 2010). O que acontece no Rio de Janeiro pode ser uma indicação do que poderá acontecer, nas próximas décadas, no restante do Brasil.

Além desta introdução, este artigo traça um breve histórico da evolução do crescimento dos segmentos católicos e evangélicos, discute o surgimento do mercado religioso e analisa a expansão dos evangélicos no Brasil a partir da teoria da Inovação/Difusão. Mostra os dados da transição religiosa em curso no Brasil, dando destaque para o pioneirismo do Estado do Rio de Janeiro e faz uma análise espacial da difusão evangélica no território fluminense. Por fim, são apresentadas as considerações finais e a bibliografia.

\section{Breve Histórico dos Católicos e Evangélicos}

A Igreja Católica (católico significa universal) cresceu e tornou-se religião oficial do Império Romano. Quando houve a divisão entre o Império Ocidental e Oriental, o Papa de Roma e o Patriarca de Constantinopla passaram a disputar poder, gerando o "Grande Cisma”, que deu origem à Igreja Católica, do lado ocidental e a Igreja Ortodoxa, do lado oriental da Europa. A Igreja Católica se difundiu por toda a Europa Ocidental durante a Idade Média e se expandiu para as Américas, depois da conquista de Cristóvão Colombo, de 1492, e para outros continentes, especialmente após as Grandes Navegações.

Em 1517, teve início a Reforma Protestante, quando Martinho Lutero publicou as "95 Teses" criticando a condução do cristianismo e a venda de lugares no paraíso (as indulgências). Os protestantes defendiam a ideia de que todo cristão 
pudesse ler as Escrituras e interpretá-las, recusando a ideia do Papa como único líder da igreja. Eles se declaravam seguidores do Evangelho e dos princípios da "Sola Scriptura", o que significa, para os protestantes, que apenas a Bíblia era fonte de revelação suprema. Neste sentido, os termos "protestantes" e "evangélicos" são sinônimos. A inovação trazida pela Reforma Protestante se fundamenta em 5 princípios (ELIADE, 1999): 1) Sola scriptura (Somente a Escritura), é o princípio no qual a Bíblia tem primazia em relação à Tradição; 2) Sola gratia (Salvação Somente pela Graça) é o princípio que afirma que a salvação é apenas pela graça de Deus e que podemos ser resgatados de Sua ira apenas por Sua graça; 3) Sola fide (Salvação Somente pela Fé) é o princípio que afirma que a justificação é pela graça e pela fé em Cristo; 4) Solus Christus (Somente Cristo) afirma que a salvação é encontrada somente em Cristo; 5) Soli Deo gloria (Glória somente a Deus) afirma que a salvação é de Deus e foi alcançada por Deus apenas para Sua glória.

Estas inovações na doutrina cristã foram seguidas pela difusão da influência protestante (evangélica) por grande parte da Europa não mediterrânea, impulsionada também por razões políticas e sociais, já que muitos nobres desejavam apoderar-se das riquezas da igreja romana e ter controle das economias locais e nacionais. A doutrina protestante se difundiu com força, em especial, entre as classes dominantes. Lutero, por exemplo, foi contra a revolta camponesa iniciada em 1524, que visava uma sociedade sem diferenças entre ricos e pobres e sem propriedade privada.

Os evangélicos tradicionais, ou de missão, se dividem em Luteranos, Calvinistas, Anglicanos, Batistas e Metodistas. No seio destas correntes encontramse muitas pessoas bem posicionadas no topo da hierarquia social (com maiores níveis de renda e educação), cabendo a seguinte constatação de Weber (1967, p. 12): "o fato que os homens de negócios e donos do capital, assim como os trabalhadores mais especializados e o pessoal mais habilitado técnica e comercialmente das modernas empresas é predominantemente protestante".

Mas uma novidade ocorrida no início do século XX nos Estados Unidos, especificamente no Kansas, teve importância fundamental para a difusão da 
mensagem evangélica nas classes sociais com menores níveis de renda e educação. O Pentecostalismo (referência à festa de Pentecostes) surgiu a partir de uma organização que misturava a prática da cura divina, assistência espiritual e material a pessoas pobres e treinamento para jovens que desejavam ingressar nas atividades missionárias. Charles Parham (1873-1929) é considerado o pai do reavivamento pentecostal do século XX e responsável pelo início desta nova onda de difusão evangélica na América do Norte e no mundo. Logo depois, William Seymour (18701922), um negro, filho de ex-escravos da Louisiana, utilizando um templo abandonado de uma Igreja Metodista Africana, em Los Angeles, em 1906, chamou atenção ao utilizar gritos, convulsões, profecias, glossolalias, curas, milagres, prodígios e toda sorte de coisas para difundir a fé pentecostal. Estes dois exemplos mostram que o monopólio dos instrumentos de salvação não estava mais com as igrejas de primeira linha e que havia oportunidade para novos empreendedores religiosos. Desta forma, pessoas simples se tornaram líderes religiosos, com novos produtores religiosos e com um novo público alvo a ser conquistado.

O “tsunami” pentecostal chegou ao Brasil em três grandes ondas. A primeira onda, chamada de "pentecostalismo clássico" (MARIANO, 1996) teve início em 1910 com a fundação da Congregação Cristã no Brasil e, em 1911, com a Assembleia de Deus. Segundo Silva (2007):

As práticas do pentecostalismo clássico caracterizam-se por enfatizar o 'dom de línguas', a crença na volta iminente de Cristo, a salvação paradisíaca e pelo comportamento de radical sectarismo e asceticismo de rejeição do mundo exterior. Além disso, seus adeptos eram de classes menos favorecidas, rejeitados pelos protestantes históricos e perseguidos pela Igreja Católica. (SILVA, 2007, p. 3).

A segunda onda Pentecostal no Brasil começou em 1950 quando dois missionários da International Church of The Foursquare Gospel vieram ao Brasil e fundaram a Igreja do Evangelho Quadrangular (I.E.Q), construindo um pequeno templo em São João da Boa Vista, em 1951. Eles criaram a Cruzada Nacional de 
Evangelização e iniciaram o evangelismo baseado na cura divina. Nesta segunda onda houve fragmentação denominacional com o surgimento das igrejas Brasil para Cristo (1955, São Paulo), Deus é Amor (1962, São Paulo), Casa da Benção (1964, Minas Gerais) e inúmeras outras. Mariano (1996, p. 25) denomina esta fase de "pentecostalismo neoclássico", caracterizado: "pela ênfase teológica na cura divina, pelo intenso uso do rádio (que, por sectarismo, até a década de 50 não era usado pelas igrejas pentecostais, aqui existentes) e pelo evangelismo itinerante em tendas de lona”.

A terceira onda - chamada Neopentecostal - começou em 1970 e deu origem a Igreja Universal do Reino de Deus, fundada pelo Bispo Edir Macedo (1977, Rio de Janeiro), a Igreja Internacional da Graça de Deus, fundada pelo Missionário R. R. Soares, (1980, Rio de Janeiro), a Comunidade Cristã Paz e Vida, fundada pelo Pr Juanribe Pagliarin (1982, São Paulo), Igreja Renascer em Cristo, fundada pelo Apóstolo Estevan Hernandes (1986, São Paulo), Comunidade Evangélica Sara Nossa Terra, fundada pelo Bispo Robson Rodovalho (1992, Brasília) e Igreja Mundial do Poder de Deus, fundada pelo Apóstolo Valdemiro Santiago (1998, São Paulo). Segundo Mariano (1996):

Todas apresentam poucos traços de seita, forte tendência de acomodação ao mundo, participam da política partidária e utilizam intensamente a mídia eletrônica. Caracterizam-se por: (1) pregar e difundir a Teologia da Prosperidade, defensora do polêmico e desvirtuado adágio franciscano 'é dando que se recebe' e da crença nada franciscana de que o cristão está destinado a ser próspero materialmente, saudável, feliz e vitorioso em todos os seus empreendimentos terrenos; (2) enfatizar a guerra espiritual contra o Diabo, seu séquito de anjos decaídos e seus representantes na terra, identificados com as outras religiões e sobretudo com os cultos afrobrasileiros; (3) não adotar os tradicionais e esteriotipados usos e costumes de santidade, que até pouco figuravam como símbolos de conversão e pertencimento ao pentecostalismo (MARIANO, 1996, p. 26).

A maioria das igrejas neopentecostais foram criadas por divergências a partir de uma matriz original. Por exemplo, a Igreja Universal surgiu da divergência entre Edir Macedo e o Padre McAlister, da Igreja de Nova Vida. Da Universal sugiram as Igrejas Internacional da Graça e Mundial lideradas, 
respectivamente por R. R. Soares e Valdemiro Santiago e assim tantas outras. O fato é que esta característica descentralizada e de certa forma pulverizada ajuda a se adaptar melhor às necessidades e demandas das diferentes camadas da população, ao mesmo tempo em que se ajustam às transformações sociodemográficas por que passa a sociedade brasileira.

A doutrina pentecostal e suas instituições de apoio e ajuda mútua, juntamente com conservadorismo, o ascetismo e o sectarismo das correntes iniciais - Congregação Cristã e Assembleia de Deus - tinham apelo junto aos segmentos pobres da população urbana brasileira que, antes da década de 1970, estavam excluídas do mercado de consumo e tinham baixa mobilidade social e espacial. Mas isto mudou nas últimas décadas do século XX, como afirmou Mariano (1996):

\begin{abstract}
Frente às muitas mudanças ocorridas na sociedade, sobretudo na área comportamental, e às novas demandas do mercado religioso, várias lideranças optaram por ajustar gradativamente sua mensagem e suas exigências religiosas à disposição e às possibilidades de cumprimento por parte de seus fiéis e virtuais adeptos. $\mathrm{O}$ sectarismo e o ascetismo começaram a ceder lugar à acomodação ao mundo, acompanhando o processo de institucionalização de importantes segmentos pentecostais. Nos EUA, este processo teve início já nos anos 50 e 60. No Brasil, ele é mais recente, principia nos anos 70 e se aprofunda com o nascimento e crescimento do neopentecostalismo. (MARIANO, 1996, p. 27).
\end{abstract}

Enquanto a Igreja Católica Apostólica Romana é centralizada e tem pouca flexibilidade doutrinária, as diversas igrejas Evangélicas cobrem um leque muito grande de doutrinas e normas de comportamento pessoal, familiar e social. Desta forma, pode-se dizer que existe igreja evangélica para todo tipo de gosto e para todos os segmentos de uma sociedade cada vez mais plural.

Em geral, as igrejas Evangélicas Tradicionais ou de Missão atingem as camadas sociais de mais alta renda e educação. As igrejas Pentecostais tradicionais são mais voltadas para as camadas pobres da população e defendem ideias conservadoras e de forte conteúdo moral e sectário. Mas as igrejas Neopentecostais são mais liberais em termos de comportamento e de posicionamento político, tendo mais facilidade para se aproximar das camadas médias da sociedade e mais 
capacidade de incluir segmentos minoritários ou marginalizados da população.

Alguns exemplos: a) enquanto há setores evangélicos contra o uso de métodos contraceptivos, sendo radicalmente contra o aborto - inclusive defendendo o Estatuto do Nasciturno e o direito à vida desde a concepção - há, de forma antagônica aqueles, como o Bisto Edir Macedo da Igreja Universal que defendem o planejamento familiar, a esterilização e se posiciona a favor da legalização do aborto (MACEDO, 2010); b) a Igreja Bola de Neve oferece como diferencial uma mensagem voltada ao público informal, que ressalta características como ausência de dogmas, tradições e costumes religiosos e a chamada "liberdade" de seguir Jesus sem precisar se converter a um estilo de vida muito distinto da média da sociedade. Neste sentido, a Igreja Bola de Neve tem sua imagem associada à prática de esportes radicais, tais como surf e skate, e muitos de seus templos possuem uma decoração baseada nestes esportes (BOLA DE NEVE, 2014); c) enquanto existem setores evangélicos radicalmente contra a homossexualidade e o casamento de pessoas do mesmo sexo, inclusive defendendo a chamada "cura gay”, o líder pastoral evangélico Marcos Lord se transforma na drag queen, Luandha Perón e participa da Igreja da Comunidade Metropolitana (ICM), que assim como a Metropolitan Community Church dos Estados Unidos, tem a maior parte dos fiéis integrantes da comunidade LGBT (LEONI, 2014). Estes são exemplos de mensagens que atingem um público que não é contemplado pela Igreja Católica ou pelas igrejas evangélicas tradicionais

Evidentemente a Igreja Católica também mudou nos últimos 500 anos, sendo que, mais recentemente, com as transformações socioeconômicas e culturais ocorridas depois da Segunda Guerra Mundial, houve o surgimento das Comunidades Eclesiais de Base (CEB) e o crescimento do Movimento de Renovação Carismática (MRC). Para se adaptar aos novos tempos, a Igreja Católica seguiu um duplo caminho, apoiando, por um lado, as ações de esquerda e o enfrentamento das questões sociais, tendo como base as novas diretrizes do Concílio Vaticano II (a Teologia da Libertação é uma expressão deste momento); e, 
por outro lado, seguiu um caminho mais conservador e mais adaptado aos tempos pentecostais, no que veio a formar a Renovação Carismática.

$\mathrm{Na}$ época do Papa João Paulo II houve a chamada "restauração conservadora" e atualmente o Papa Francisco volta a dar ênfase à "opção preferencial pelos pobres”. Mas segundo Prandi e Souza (1996):

o catolicismo das comunidades não tem como enfrentar o concorrente, pois padece das consequências advindas de sua concepção de indivíduo e sociedade que dá prioridade ao coletivo, em detrimento da individualidade, tão valorizada na sociedade contemporânea, mesmo quando se trata da própria concepção de fé e que é a dimensão em que se move tão facilmente o pentecostalismo e outras modalidades religiosas, com as quais o catolicismo da Libertação não é capaz de manter diálogo algum, pois se trata de mundos completamente diferente. (PRANDI; SOUZA, 1996, p. 73).

O fato é que a disputa entre católicos e evangélicos continua e se amplia no século XXI, na medida em que há uma redução do peso dos primeiros e um crescimento dos segundos, acompanhada pela diversificação e difusão das diversas denominações evangélicas por todo o território nacional, sendo que o Rio de Janeiro está na vanguarda e no centro da transição religiosa.

\section{Mercado Religioso e a Teoria da Inovação e Difusão}

O Brasil vem passando por diversas transições econômicas, sociais, culturais e demográficas: transição urbana, democrática, demográfica, epidemiológica, nutricional, da estrutura etária, de geração, dos padrões de consumo, ecológica, transição das formas de família e dos arranjos domiciliares, transição das relações de gênero e transição religiosa (ALVES, 2014).

Todas essas transições contribuíram para a constituição de um mercado de bens e serviços, o que é um pré-requisito para a formação de um mercado religioso, fenômento inexistente em uma economia de subsistência, não monetizada e com baixa diversificação da cesta de consumo. Nos primeiros 450 anos do monopólio 
católico no Brasil, a noção de "escolha religiosa" não fazia muito sentido, pois quase a totalidade da população nascia em berço católico e as possibilidades de migração espacial, social e religiosa eram pequenas.

As novas características sociodemográficas da sociedade brasileira já estavam evidentes no início dos anos de 1980, no momento da redemocratização do país. Foi também na década de 1980 que a teoria da escolha racional passou a ser aplicada à religião, especialmente depois dos trabalhos de Rodney Stark (1985). Segundo Mariano (2008, p. 43), da mesma forma que a racionalidade econômica pressupõe que "os seres humanos buscam o que percebem ser recompensas e evitam o que percebem ser custos", no plano religioso "as pessoas fazem escolhas da mesma maneira que fazem outras escolhas, pesando custos e benefícios”.

Mesmo reconhecendo que a dinâmica religiosa não se resume a simples decisões racionais, a ideia de um mercado religioso é útil para entender a disputa entre as diversas Igrejas pelo crescimento do número de filiados. Segundo Frigerio (2008), com base em Stark, o único fator que pode impedir que se desenvolva uma variedade de religiões para atender a segmentos específicos do mercado é a existência de um monopólio religioso sustentado pelo Estado: “Uma economia religiosa não regulada, impulsionada pelo mercado, levará ao crescimento da pluralidade religiosa" (FRIGERIO, 2008, p. 23). Em uma sociedade heterogênea e democrática, as demandas específicas dos diversos segmentos da população tendem a gerar uma pluralidade na oferta religiosa.

Segundo Guerra (2003), nas sociedades contemporâneas, em que os indivíduos são crescentemente orientados para decidir livremente a respeito de que modelo de religiosidade vão adotar (inclusive declarar-se sem religião), o que as organizações religiosas oferecem tem que ser atrativo para os potenciais consumidores: 
A lógica mercadológica sob a qual a esfera da religião opera produz, entre outras coisas, o aumento da importância das necessidades e desejos das pessoas na definição dos modelos de práticas e discursos religiosos a serem oferecidos no mercado. Ao mesmo tempo, demanda das organizações religiosas maior flexibilidade em termos de mudança de seus "produtos" no sentido de adequá-los da melhor maneira possível para a satisfação da demanda religiosa dos indivíduos. (GUERRA, 2003, p. 1).

Desde que a religião passou a ser, em grande parte, objeto de escolha das pessoas, o que determina o crescimento de uma determinada denominação é a eficácia dos modelos de religiosidade e seus significados oferecidos à massa de fiéis de determinados segmentos populacionais. Como a sociedade contemporânea é plural e marcada por fortes desigualdades sociais, os discursos e práticas religiosas se voltam para tornar o produto religioso ofertado mais eficiente na satisfação das necessidades religiosas básicas dos fiéis.

Enquanto a Igreja Católica, com toda a sua rígida hierarquia, tende a ter pouca flexibilidade para diversificar seus produtos religiosos (tendo disputas e divergências internas entre as CEBs e o MRC), as inúmeras denominações pentecostais e neopentecostais encontram-se com mais liberdade e melhor posicionadas para oferecer produtos singulares para comunidades e segmentos populacionais específicos, atendendo diferentes nichos de mercado.

Diversos autores, como Oro (1992), afirmam que as igrejas neopentecostais adotam um modelo empresarial na gestão da organização eclesiástica na sua organização interna e nos mecanismos de arrecadação de recursos. O neopentecostalismo, em geral, se caracteriza pela "comercialização" de bens simbólicos e do sagrado. Assim, na lógica mercadológica, as correntes pentecostais e neopentecostais utilizam melhor as noções de customização e fidelização.

Segundo os manuais de administração, a customização significa fazer produtos "sob encomenda", ou atender de forma diferenciada cada segmento do mercado. No caso da disputa entre as igrejas, a customização pode significar a oferta de produtos religiosos em massa para atender aos anseios específicos de determinados tipos de "clientes", segundo características socioeconômicas ou 
preferências comportamentais. Para a divulgação de produtos customizados o marketing direto e a mídia eletrônica são soluções frequentes. A fidelização visa reter os clientes (fidelização dos fiéis), garantir espaço frente aos concorrentes e manter uma boa participação no mercado (religioso). "Clientes" fiéis não apenas consomem os produtos de determinada "marca religiosa", mas também podem exercer um importante papel como defensores da "marca" e divulgadores da mesma entre seus familiares, parentes, amigos, colegas de trabalho e vizinhos. A propaganda boca a boca é de grande eficiência para a customização e a fidelização da mensagem religiosa. Desta forma, as denominações pentecostais e neopentecostais, ao customizar seus produtos, conseguem maior fidelização dos seus fiéis, garantindo crescentes fatias de mercado.

O mercado religioso e a lógica mercadológica ganham maior relevância na sociedade pós-moderna em que as velhas identidades, que estabilizavam o mundo social, entram em declino, fazendo surgir novas identidades e fragmentando o indivíduo moderno, até então visto como um sujeito unificado. No processo mais amplo de transições sociodemográficas e culturais, a chamada "crise de identidade" é parte de uma fragmentação das estruturas modernas que davam aos indivíduos uma ancoragem estável no mundo social (BAUMAN, 2004). Assim, Zygmunt Bauman descreve a pós-modernidade como um tipo de sociedade marcada pela consciência e práxis autônomas, com fortalecimento do processo de individuação (liberdades individuais). A passagem de uma estrutura fixa para outra de cunho flexível afeta a dinâmica religiosa, ao reforçar as expressões da consciência fragmentária, do perspectivismo em relação ao futuro, do sincretismo de visões e do desencantamento do mundo. Neste novo cenário, existe um vazio não preenchido pela religião tradicional e uma demanda por novas formas de expressões religiosas, abrindo espaço para a difusão de novas propostas. Neste contexto de demanda difusa existe espaço para a oferta de produtos religiosos específicos, o que abre espaço para a difusão de mensagens não convencionais. 
Neste sentido, a teoria da “inovação/difusão”, que já foi usada com bastante sucesso para analisar o processo de transição da fecundidade, pode ser útil para a compreensão das mudanças religiosas que acontecem no Brasil, no contexto da pluralidade do mercado religioso. Segundo Casterline (2001),

One set of alternative explanations that came to the fore has usually been collected under the label 'diffusion'. As we shall note below, the arguments classified as 'diffusion theories' vary somewhat in their emphasis, and particularly in what they regard as the unique causal contribution of diffusion theory. What unites them is an overarching model of social change in which attitudes and behaviors become more prevalent in a population through their spread from some individuals to others, through informal face-to-face social interaction or at a distance through the mass media [...]. Diffusion theory usually stresses the innovative nature of the attitudes or behaviors that spread-the common phrase is innovation diffusion'- but for most scholars this is not an essential feature of this theoretical perspective. (CASTERLINE, 2001, p. 3).

É interessante notar que as mudanças religiosas não são apenas uma adaptação às novas condições sociais, mas existe um processo ativo de afirmação de novas mensagens que se sobrepõem em ondas. Segundo Retherford e Palmore (1983), é preciso distinguir as inovações contínuas e as descontínuas, no processo de difusão. Para os autores, o ponto crucial é que a propagação de atitudes e comportamentos não está vinculada diretamente às mudanças estruturais da sociedade, em vez disso, elas têm uma dinâmica independente da macroestrutura, e, portanto, podem ser responsáveis pela maior parte da variação das tendências sociais, no caso, no ritmo e no tempo, das mudanças religiosas. $\mathrm{O}$ surgimento das mensagens pentecostal e neopentecostal representou uma inovação no campo religioso e a sua difusão avança no Brasil na medida em que novas fatias do mercado são conquistadas, acelerando o processo de transição religiosa.

\section{A Transição Religiosa no Brasil}

A Reforma Protestante, do início do século XVI, questionou diversos pontos da doutrina da Igreja Católica Romana e se difundiu na Europa e na América do Norte. No Brasil, as filiações católicas permaneceram acima de $90 \%$ do total 
populacional até fins dos anos de 1970. No espaço de 30 anos, entre 1980 e 2010, os católicos caíram de $89 \%$ para $64,6 \%$, perdendo 24,4 pontos, conforme mostra o gráfico 1. Os evangélicos, no mesmo período, passaram de 6,6\% para 22,2\%, ganhando 17,6 pontos. Outas religiões e os sem-religião passaram, em conjunto, de 4,4\%, em 1980, para 13,2\% em 2010.

\section{Gráfico 1: Percentagem de católicos e evangélicos na população brasileira: 1872 - 2010}

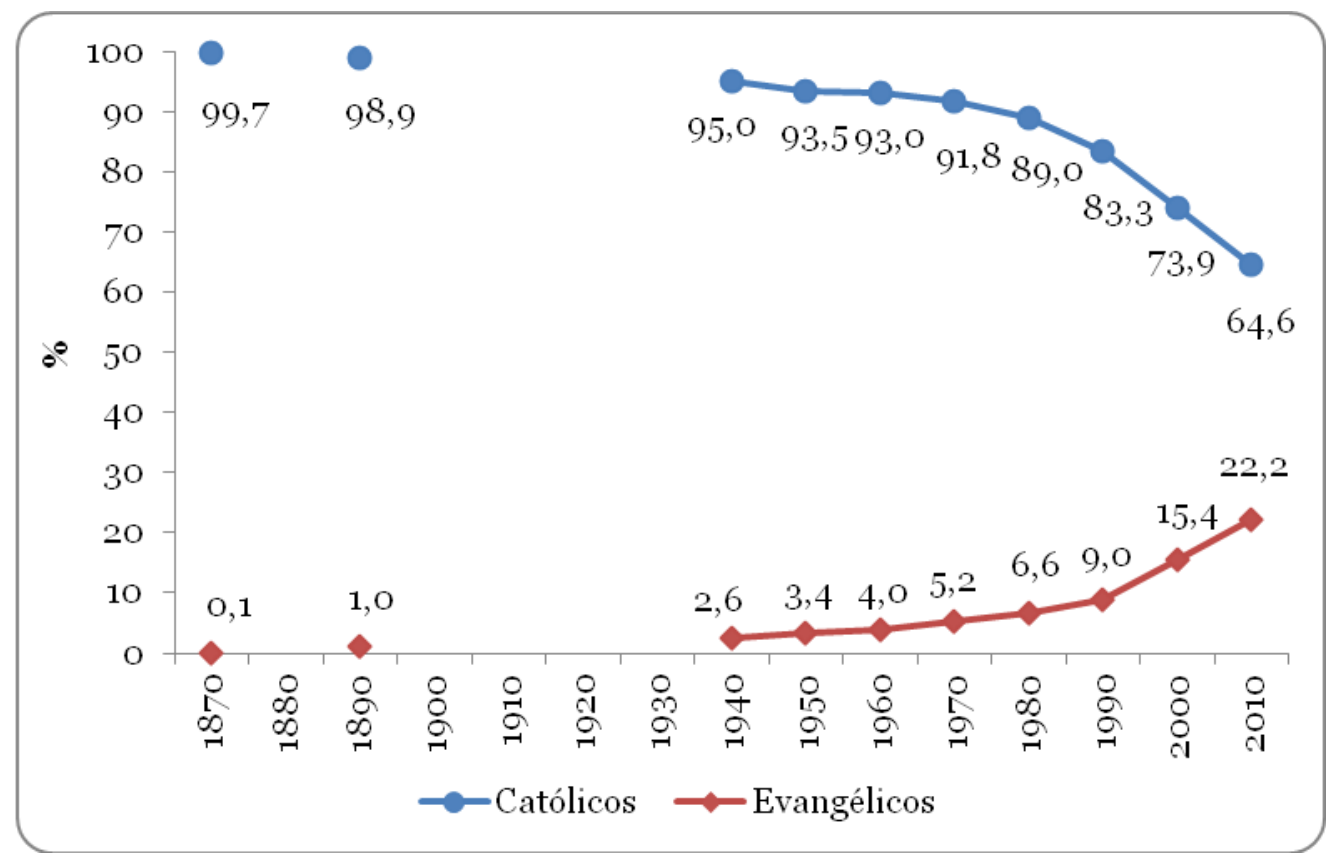

Fonte: Censos demográficos do IBGE

Assim, além da queda dos católicos e da subida dos evangélicos, houve uma diminuição das filiações cristãs e um aumento da pluralidade religiosa no país, conforme descrito por vários autores (DECOL, 1999; ALVES; BARROS; CAVENAGHI, 2012; ALMEIDA; BARBOSA, 2013; MARIANO, 2013).

Para compreender esse processo, as variáveis geracionais são essenciais e o instrumental de análise demográfica pode ajudar a esclarecer as alteraçõesintergeracionais. A transição religiosa fica mais evidente quando se leva em consideração os grupos etários, conforme mostrado no gráfico 2. Nota-se que a maior redução do percentual de católicos ocorreu nas idades mais jovens, sendo 
que entre a população idosa a redução foi bem menor. Em termos absolutos, para a população brasileira como um todo, houve um aumento de 1,5 milhões de filiações católicas entre 1991 e 2010. Considerando-se as gerações, no entanto, houve uma redução de 15,8 milhões de católicos nas idades entre o e 29 anos e um aumento de 17,2 milhões de católicos nos grupos etários de 30 ou mais anos de idade. Ou seja, independentemente do processo de migração inter-religiosa que venha a ocorrer nos próximos anos, apenas a sucessão de gerações vai manter a tendência de redução da hegemonia católica.

\section{Gráfico 2: Percentagem de católicos por grupos etários, Brasil: 1991-2010}

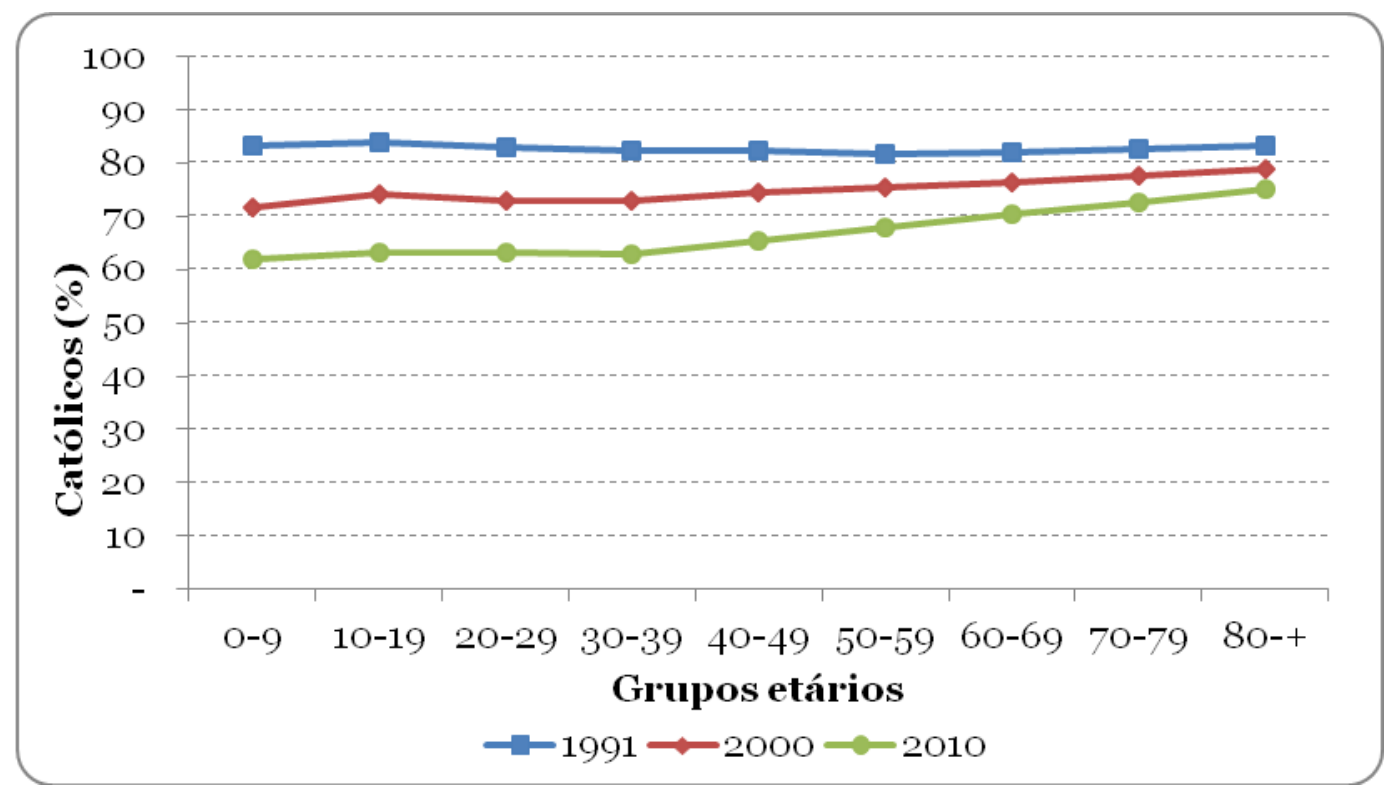

Fonte: IBGE. Censos demográficos do IBGE de 1991, 2000 e 2010.

Um fato marcante é que a queda dos católicos foi maior onde seus percentuais já eram baixos, especialmente naqueles estados em que os católicos estavam com menos de 50\% em 2010, conforme mostra o gráfico 3. 


\section{Gráfico 3: Percentagem de queda dos católicos nas 27 Unidades da Federação do Brasil entre 2000 e 2010 , segundo percentual de católicos em cada estado.}

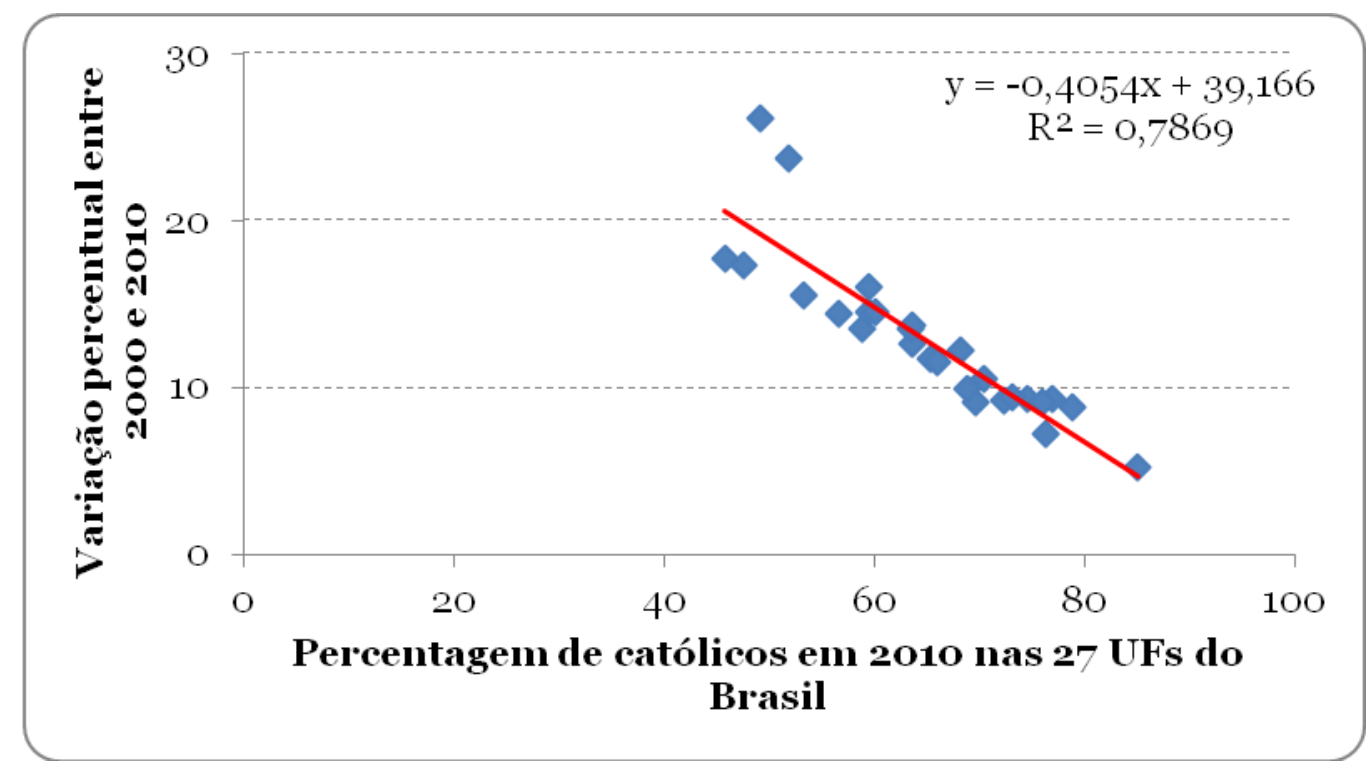

Fonte: Censos demográficos de 2000 e 2010, do IBGE

Entre 2000 e 2010 a queda no percentual de católicos foi de $26 \%$ em Roraima, 23,7\% no Acre, $17,8 \%$ no Rio de Janeiro e de 17,3\% em Rondônia. No outro extremo, o Piaú que tinha 85\% de católicos em 2010 apresentou uma queda de somente $5,3 \%$. Isto quer dizer que pluralidade religiosa gera mais pluralidade, conforme mostra o gráfico 3. Significa também que quanto maior tenha sido a queda experimentada dos católicos, maior, em média, tende a ser a queda futura. Portanto, a transição religiosa, seguindo esse padrão, deve se consolidar e se aprofundar nas próximas décadas.

\section{O Pioneirismo do Rio de Janeiro, o Crescimento da Pluralidade e a Mudança de Hegemonia Religiosa}

O Estado do Rio de Janeiro é a Unidade da Federação com menor percentual de católicos $(45,8 \%)$, o menor percentual de cristãos $(75,2 \%)$ e a maior pluralidade religiosa, estando na vanguarda das transformações religiosas do Brasil. Segundo o censo demográfico de 2010, do IBGE, os católicos representavam 
64,6\% no Brasil e 45,8\% no Rio de Janeiro, os evangélicos eram 22,2\% no Brasil e 29,4\% no Rio de Janeiro, as outras religiões eram, respectivamente, 5,2\% e 9,2\% e os sem-religão eram 8\% no Brasil e 15,6\% no Rio de Janeiro. A população fluminense não é a que apresenta os maiores percentuais de evangélicos do Brasil, mas é a que apresenta a menor proporção de católicos e a maior proporção de semreligião e de outras religiões. Os cristãos (católicos + evangélicos) somaram 75,2\% no estado, o menor percentual do Brasil. Estes dados reforçam o foco da análise da transição religiosa no território fluminense.

O Rio de Janeiro é ainda a Unidade da Federação com maior diversidade religiosa do país. Os dados sugerem também que quanto maior é a disputa entre católicos e evangélicos mais crescem as outras religiões e os sem-religião, favorecendo a pluralidade. Portanto, estudar a difusão das filiações evangélicas ajuda a entender o processo de ampliação da diversidade religiosa em suas diferentes escalas.

Não só na religião, mas também em outros campos, o Rio de Janeiro é o estado que apresenta as maiores transformações sociodemográficas do Brasil, sendo reconhecido como um foco de inovação e difusão de novos comportamentos que assumem dimensões nacionais. O Estado fluminense possui várias características que o destaca das demais Unidades da Federação: a) Maior densidade demográfica; b) Maior percentual de população urbana; c) Maior concentração populacional metropolitana; d) Maior índice de envelhecimento; e) Menor razão de sexo; f) Menor taxa de fecundidade total; g) Menor razão de dependência demográfica.

O pioneirismo do Rio de Janeiro em termos social, demográfico e cultural pode ser um indicador antecipado das transformações nacionais. O território fluminense de hoje pode indicar o Brasil de amanhã ("sou você amanhã"). Em termos sociodemográficos a cidade do Rio de Janeiro, que foi capital do Brasil de 1763 a 1960, tem liderado o processo de modernização, especialmente em termos culturais. Mas em termos de aumento da pluralidade religiosa e da difusão dos 
evangélicos (especialmente pentecostais e neopentecostais), o pioneirismo tem cabido à periferia da Região Metropolitana do Rio de Janeiro.

A tabela 1 mostra que os católicos, no Brasil, perderam 18,4 pontos percentuais de 1991 a 2010, representando uma perda média de quase 1 ponto percentual ao ano. No estado do Rio de Janeiro a perda foi de 21,5\% em 19 anos. Na Periferia da Região Metropolitana do Rio de Janeiro - PRMRJ (municípios da Região Metropolitana menos a capital) a perda dos católicos em 19 anos foi de $22,5 \%$, ou seja, uma redução média de mais de 1 ponto percentual ao ano. $\mathrm{Na}$ cidade do Rio de Janeiro, a capital fluminense, a perda foi de 18,7\% em 19 anos. Em 1991, a diferença entre o percentual de católicos da PRMRJ e do Brasil foi de 21,8 pontos percentuais, em 2000 foi de 26,7 pontos e, em 2010, a diferença foi de 27,2 pontos.

Isto quer dizer que a Periferia da Região Metropolitana do Rio de Janeiro, que em 2010 tinha uma população de 5,5 milhões de habitantes, tem mantido uma dianteira de pouco mais de 20 anos em relação à média das tendências brasileiras. Desta forma, o percentual de católicos do Brasil em 2010 estava próximo do percentual de católicos da Periferia da Região Metropolitana do Rio de Janeiro de 20 a 25 anos antes. Mantido esse ritmo, o percentual de católicos do Brasil em 2040 pode ser correspondente ao percentual de católicos da PRMRJ em 2010, ou seja, menos de $40 \%$.

\section{TABELA 1}

Percentagem de católicos do Brasil, Estado do Rio de Janeiro (ERJ) e Periferia da Região Metropolitana do RJ (PRMRJ) e diferença em pontos percentuais por década, 1991, 2000 e 2010.

\begin{tabular}{cccccccccc}
\hline \multirow{2}{*}{ Religião } & \multicolumn{3}{c}{1991} & \multicolumn{3}{c}{2000} & \multicolumn{3}{c}{2010} \\
\cline { 2 - 9 } & Brasil & ERJ & PRMRJ & Brasil & ERJ & PRMRJ & Brasil & ERJ & PRMRJ \\
\hline Católicos & 83,0 & 67,3 & 61,2 & 73,9 & 55,7 & 47,2 & 64,6 & 45,8 & 37,4 \\
Diferença & & 15,7 & 21,8 & & 18,2 & 26,7 & & 18,8 & 27,2 \\
\hline
\end{tabular}


O fato é que a queda do percentual de católicos na periferia da Região Metropolitana do Rio de Janeiro tem sido impressionantemente rápida e o aumento da diversidade religiosa tem sido acentuado. Além disto, as inovações ocorridas na PRMRJ têm se difundido para outros municípios do estado. Dos 92 municípios fluminenses, em 2000, havia apenas um município (Silva Jardim) onde os evangélicos superavam os católicos. Mas em 2010, os evangélicos superavam os católicos em 18 municípios do estado.

Na região metropolitana os católicos só possuem percentual acima de 50\% das filiações religiosas nas cidades de Niterói e do Rio de Janeiro. Dos 21 municípios da Região Metropolitana, os evangélicos superam os católicos em 13 e perdem de pouco em apenas 4 municípios. Na periferia da Região Metropolitana (sem a cidade do Rio de Janeiro) os católicos caíram de 46,6\% em 2000 para 37,4\% em 2010, enquanto os evangélicos subiram de 27,1\% para 34,5\% no mesmo período. A queda dos católicos foi maior do que a subida dos evangélicos. Isto ocorreu porque as outras religiões, passando de 5,7\% para 8,3\%, ganharam peso relativo na década.

Entretanto, considerando a população de o a 14 anos os evangélicos já superam os católicos em 2010. A maior força dos católicos está na população idosa. Desta forma, independentemente da migração entre diferentes correntes religiosas, a sucessão de gerações vai favorecer os evangélicos que estão melhor posicionados nas gerações mais jovens.

\section{TABELA 2}

Percentagem dos grupos religiosos na periferia da Região Metropolitana do Rio de Janeiro, por grupos etários: 2000 e 2010.

\begin{tabular}{ccccccccc}
\hline \multirow{2}{*}{$\begin{array}{c}\text { Total e } \\
\text { grupos } \\
\text { etários }\end{array}$} & \multicolumn{2}{c}{ Católica } & \multicolumn{2}{c}{ Evangélica } & \multicolumn{2}{c}{ Outras } & \multicolumn{2}{c}{ Sem religião } \\
\cline { 2 - 9 } & 2000 & 2010 & 2000 & 2010 & 2000 & 2010 & 2000 & 2010 \\
\hline Total & 46,6 & 37,4 & 27,1 & 34,5 & 5,7 & 8,3 & 20,6 & 19,7 \\
\hline $0-14$ & 41,0 & 32,1 & 28,7 & 39,0 & 4,6 & 6,9 & 25,7 & 22,1 \\
$15-64$ & 47,9 & 37,8 & 26,5 & 33,5 & 6,0 & 8,7 & 19,6 & 20,0 \\
$65-+$ & 56,4 & 49,8 & 27,3 & 30,9 & 6,9 & 9,3 & 9,4 & 10,1 \\
\hline
\end{tabular}

Fonte: Censos Demográficos de 2000 e 2010 do IBGE 
A periferia da Região Metropolitana tem liderado o processo de diversificação religiosa do estado do Rio de Janeiro, enquanto esta Unidade da Federação tem liderado as transformações religiosas do país. Conhecer e reconhecer as mudanças na hegemonia religiosa que ocorrem na Região Metropolitana e o processo de difusão das filiações evangélicas no estado do Rio de Janeiro pode ajudar a compreender e antecipar o que pode ocorrer no restante do país.

O gráfico 4 mostra que o percentual de católicos sempre foi um pouco mais baixo no território fluminense e que as curvas das filiações de católicos e evangélicos no Estado do Rio de Janeiro estão se aproximando mais rapidamente do ponto de contato e empate (comparado ao Brasil como um todo, conforme mostrado no gráfico 1), o que deve acontecer até 2020. Se as tendências se mantiverem, o Rio de Janeiro pode ser a primeira UF em que os evangélicos irão superar os católicos.

\section{Gráfico 4: Percentagem de católicos e evangélicos na população fluminense: $1872-2010$}

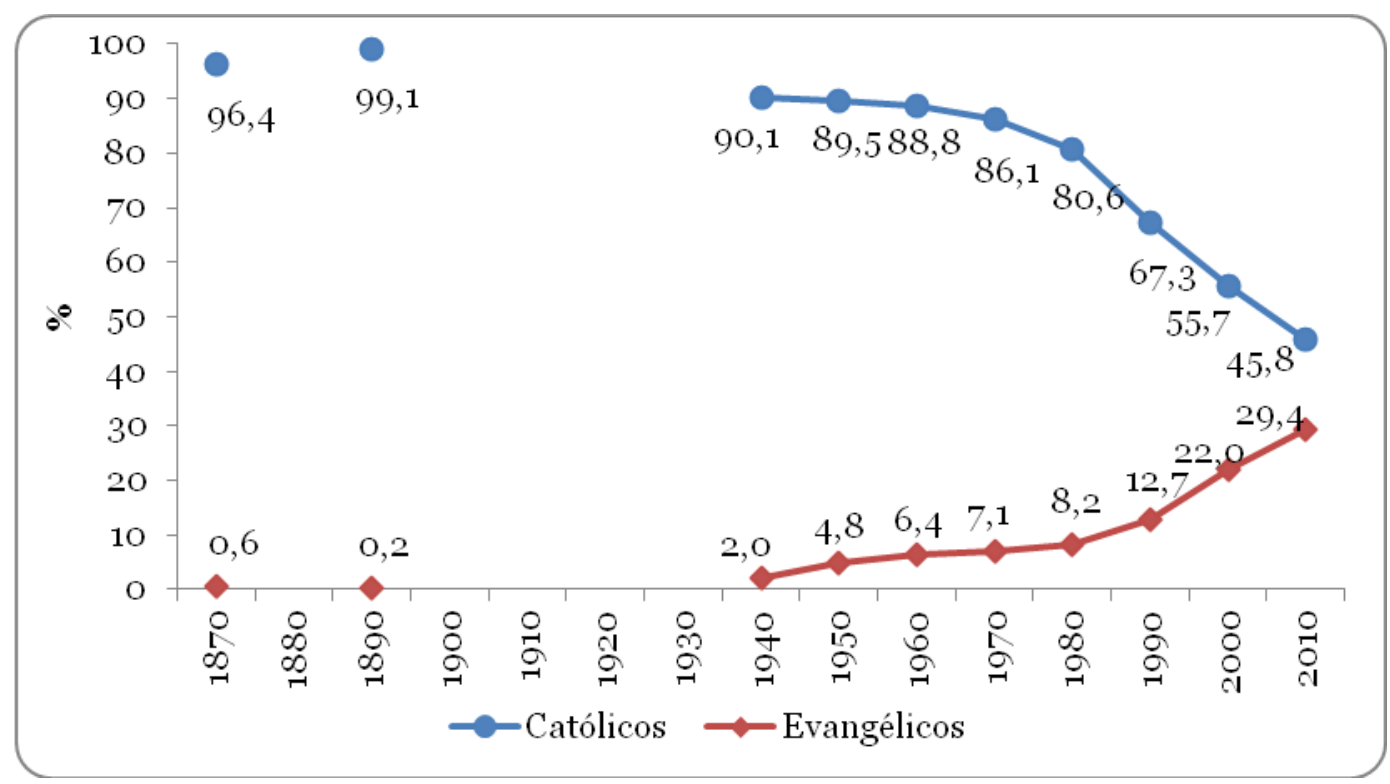

Fonte: Censos demográficos do IBGE 
Assim como no Brasil (gráfico 3), a queda dos católicos foi maior onde seus percentuais já eram baixos, especialmente naqueles municípios em que os católicos estavam com menos de 50\% em 2010, conforme mostra o gráfico 5. Entre 2000 e 2010 a queda no percentual de católicos foi de impressionantes 40\% na cidade de Carapebus e de 31,4\% na cidade de Queimados. Por outro lado, os católicos cresceram ligeiramente nos municípios de São José de Ubá e Macuco, onde os percentuais das filiações católicas já eram altos e continuam acima de dois terços do total populacional.

De maneira mais acentuada do que a do conjunto do Brasil, a pluralidade religiosa no Rio de Janeiro tem gerado maior pluralidade religiosa, sem haver um piso aparente. Municípios como Seropédica e Japeri tiveram grandes variações nas filiações religiosas na primeira década do século XXI e os católicos já são menos de 30\% nestas duas cidades. Portanto, a transição religiosa tende a se consolidar e a se aprofundar mesmo no Estado do Rio de Janeiro, onde o processo de mudança de hegemonia já está mais avançado.

\section{Gráfico 5: Percentagem de queda dos católicos nos 92 municípios do Estado do Rio de Janeiro, entre 2000 e 2010, segundo percentual de católicos em cada cidade.}

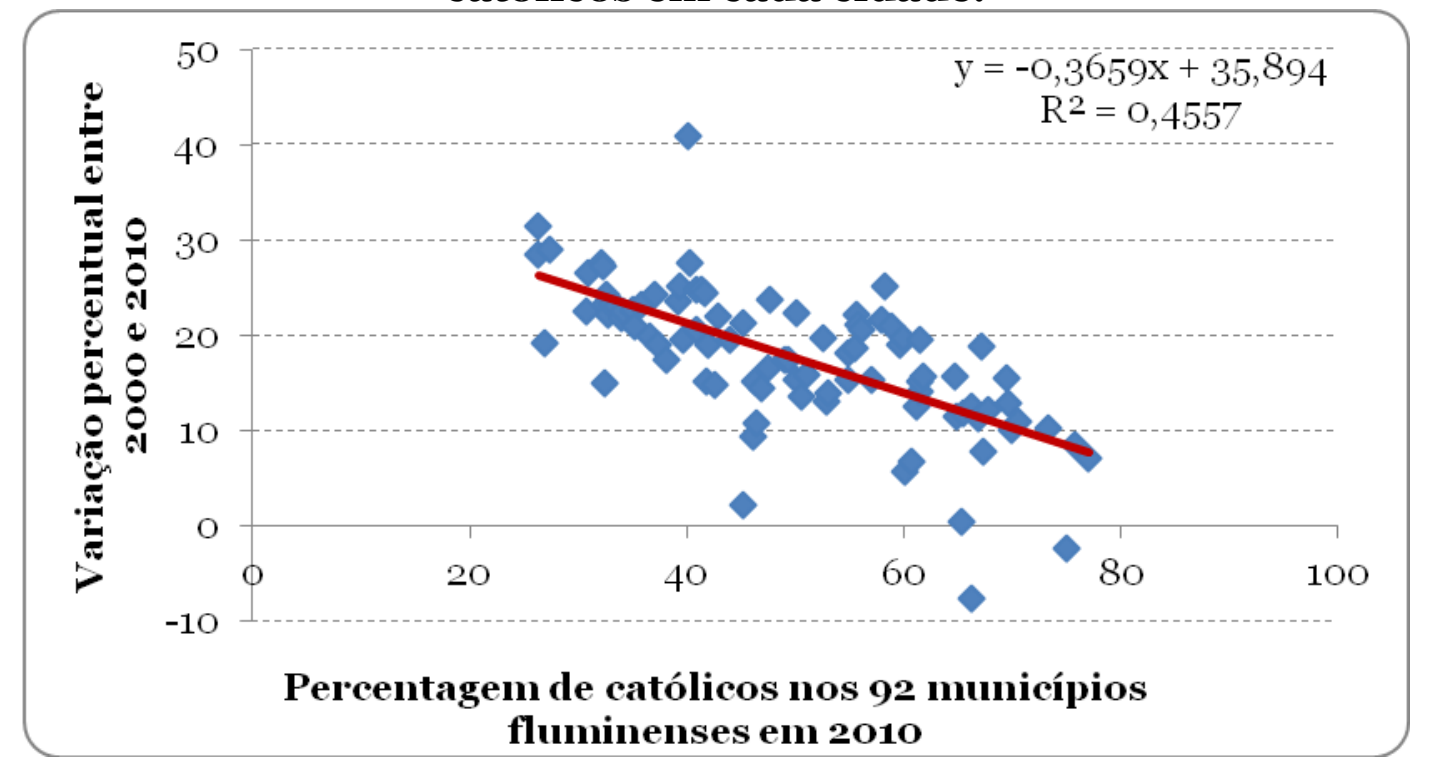

Fonte: Censos demográficos de 2000 e 2010, do IBGE 
A cidade de Seropédica, por exemplo, é um exemplo de rápida mudança religiosa. Até o início dos anos de 1990, Seropédica fazia parte do município de Itaguaí. No censo demográfico de 1991, Itaguaí tinha $55 \%$ de pessoas que se declaravam católicas e $21 \%$ de evangélicos. Em Seropédica, houve quase um empate no ano 2000, com os evangélicos atingindo 35,9\% e os católicos 38,8\%. As outras religiões perfaziam um percentual de $5,3 \%$ e os sem religião 20,1\%. Na primeira década do século XXI a mudança continuou de maneira acelerada entre a população total do município, com os católicos caindo para 27,4\% em 2010, os

evangélicos subindo para $44 \%$, as outras religiões para $6,3 \%$ e os sem religião subindo para 22,3\%. Portanto, entre 1991 e 2010, os católicos de Seropédica caíram de mais de $50 \%$ para cerca de um quarto (25\%). Foi uma perda muito acelerada e parece que não vai ser interrompida imediatamente, pois os católicos estão mais representados entre os idosos e os evangélicos mais representados entre as mulheres em período reprodutivo e as novas gerações. Independentemente da migração inter-religiosa, haverá mudança apenas por conta da inércia demográfica e da sucessão de gerações.

De certa forma, os neopentecostais, com todas as flexibilizações do discurso e das normas de comportamento, se transformam na última alternativa, antes das pessoas procurarem a saída da prática religiosa cotidiana. $\mathrm{O}$ reencantamento acaba por se tornar desencantamento do mundo e a porta de saída das práticas religiosas e de fortalecimento, por vias tortas, do processo de secularização.

\section{1 “Estradas da Fé”: os Caminhos da Difusão Evangélica no Rio de Janeiro}

Como visto, o Brasil está passando por profundas mudanças no perfil religioso de sua população e o Estado do Rio de Janeiro é a Unidade da Federação em que há maior diversidade religiosa e onde os católicos apresentam os menores percentuais do país. 
Dentre as 92 cidades do estado, em 2000, havia apenas um município (Silva Jardim) onde os evangélicos superavam os católicos. Mas em 2010, o número passou para 18 municípios. A queda do percentual de católicos foi maior onde o percentual já era baixo e a diversidade religiosa era mais alta. Ou seja, ao invés de ter um piso, no processo de mudança de hegemonia a queda do percentual de católicos tende a se aprofundar e não a se estancar.

Entre 2000 e 2010, houve aumento do percentual de católicos apenas em dois municípios pequenos: Macuco e São José de Ubá, ambos no norte fluminense, quase na fronteira com Minas Gerais e fora das rodovias mais dinâmicas do Estado. Por outro lado, em Queimados, Japeri, Silva Jardim e Seropédica o percentual de católicos estava abaixo de 30\% em 2010.

Os dados do Estado do Rio de Janeiro mostram que o processo de difusão religiosa (com a queda dos católicos e a subida dos evangélicos) segue um padrão regional e espacial (Figura 1). A difusão é muito rápida de Duque de Caxias, Nova Iguaçu, Queimados até Seropédica, ou seja, da Baixada Fluminense até a Serra das Araras pela rodovia 116 (rodovia Dutra), Na direção norte, outro vetor de mudança vai de São Gonçalo rumo a Itaboraí, Tanguá, Silva Jardim, etc. Ou seja, em torno da BR 101, indo até Cabo Frio e Macaé. Na direção sul, o processo de difusão segue a rodovia Rio-Santos, onde o percentual de evangélicos cresce em Mangaratiba, Angra dos Reis e Paraty, mas se mantém baixo na cidade de Rio Claro, que não é cortada nem pela Dutra (rodovia BR 116) e nem pela Rio-Santos (rodovia BR 101).

Os católicos fluminenses mostram maior resistência à mudança em torno da rodovia 040 - que liga a cidade do Rio de Janeiro a Juiz de Fora - e nos municípios da fronteira com o Estado de Minas Gerais, que é uma Unidade da Federação onde os católicos ainda detinham 70,4\% das filiações religiosas, em 2010. Como mostraram Alves e Novelino (2006): 
O Brasil vem passando por um processo de mudança religiosa e cultural, com difusão da mensagem evangélica que acontece de baixo para cima, em termos sociais, da periferia para o centro, em termos espaciais, do meio urbano para o rural em termos de situação do domicílio, dos negros para os brancos, em termos étnicos-raciais, dos jovens para os idosos, em termos de geração, e das mulheres para os homens, em termos de gênero. (ALVES; NOVELINO, 2006, p. 306).

Os dados do censo demográfico de 2010 mostram que, pelo menos no Estado do Rio de Janeiro, o processo de difusão dos evangélicos (principalmente pentecostais e neopentecostais) também segue um padrão espacial que avança pelas principais rodovias do Estado, tendo como centro de difusão a periferia da Região Metropolitana Fluminense.

\section{Figura 1: Percentagem de evangélicos sobre católicos para os 92 municípios do Rio de Janeiro: 2000-2010}
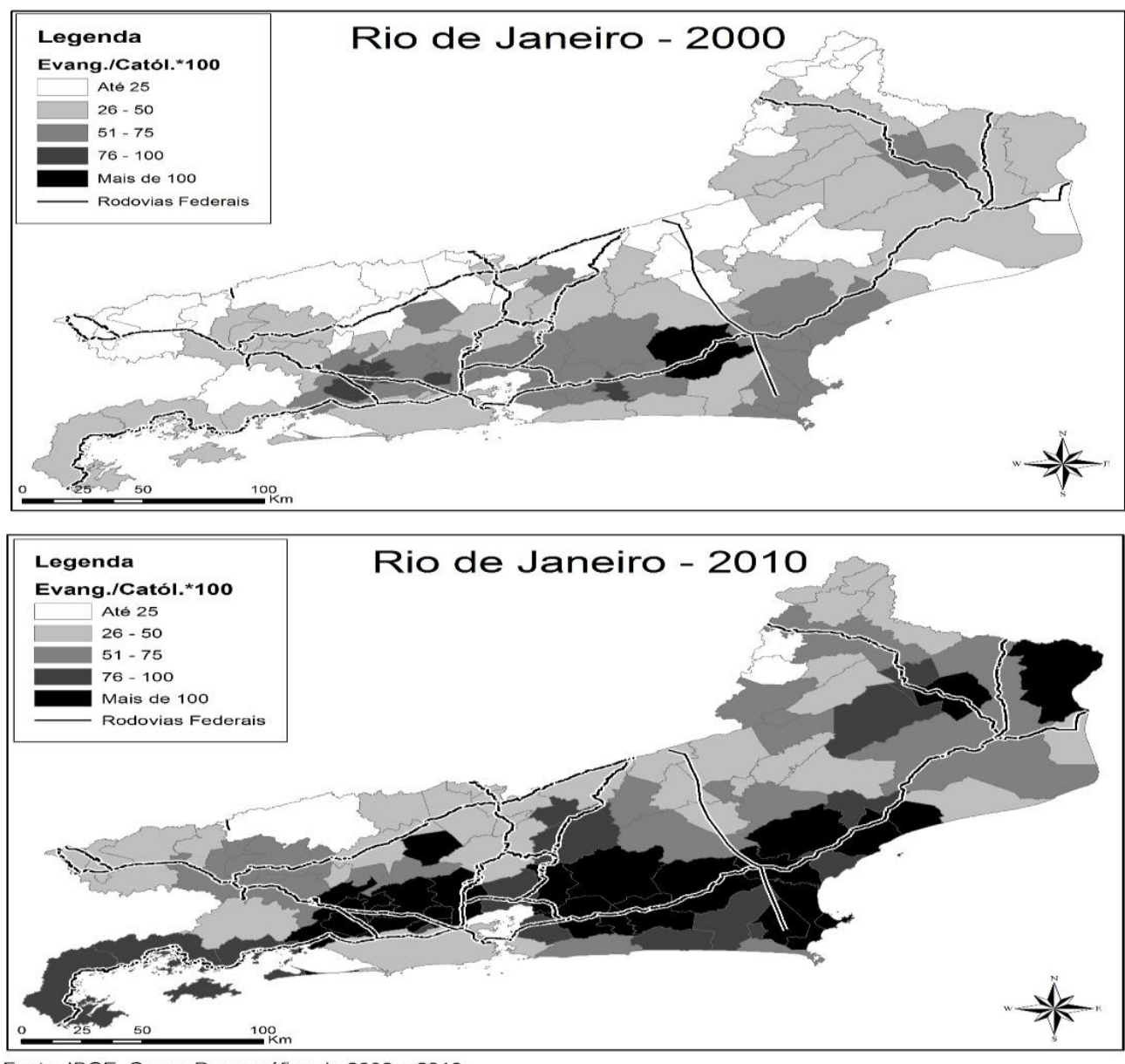

Fonte: IBGE, Censo Demográfico de 2000 e 2010 


\section{Considerações Finais}

A análise deste texto, considerando a dinâmica geoestratégica da disputa religiosa, partiu do global para o local e retornou do local para o global. As grandes mudanças do mundo acontecem na escala macroespacial, mas precisam ter uma base microespacial. De maneira sintética, pode-se dizer que qualquer mudança sociodemográfica requer uma inovação - que implica em novidades em termos de conteúdo - e vetores específicos de difusão. Desta forma, a transição religiosa, assim como a transição demográfica, possuem diversos determinantes, mas avançam por meio do processo de inovação e difusão.

Algumas das principais inovações trazidas pelo movimento pentecostal e neopentecostal são: Unidade em Cristo ("um só Espírito"; "um só Senhor” e "um Deus e Pai”); Rejeição ao intelectualismo teológico; Renascimento pela fé em Cristo; Falar em línguas (glossolalia); Cura pela fé; Teologia da prosperidade, dentre outras. As novas mensagens trazidas pelas denominações pentecostais e neopentecostais, em suas diversas modalidades, encontraram resistências mas também aceitação. Ao contrário do protestantismo clássico europeu que se difundiu entre a nobreza e avançou juntamente com as camadas mais ricas e educadas da sociedade, as correntes pentecostais encontraram terreno fértil entre os segmentos mais pobres da população, em especial, a periferia das Regiões Metropolitanas.

A transição religiosa se acelerou no Brasil após uma série de transformações estruturais (urbanização, industrialização, ampliação e diversificação do padrão de consumo, integração de transportes e telecomunicações, ampliação das políticas de proteção social, etc.) e o surgimento de um mercado de bens e serviços de caráter integral e nacional. Neste novo contexto, surgiu e cresceu o mercado religioso. Aumentou a oferta religiosa com a ampliação do leque de denominações, o que gerou maior pluralidade religiosa. Da mesma forma, como em outros processos sociodemográficos, a transição religiosa no Estado do Rio de Janeiro começou mais 
cedo do que em outros Estados brasileiros. Como pluralidade tende a gerar mais pluralidade, o ritmo de queda dos católicos foi maior no território fluminense, assim como foi maior o crescimento de "outras" religiões e dos "sem-religião". Entre 1980 e 2010 os católicos caíram de 80,6\% para 45,8\% uma perda de quase 35 pontos em 30 anos. Isto representa mais de 1 ponto percentual ao ano, percentagem superior à média nacional.

Tudo leva a crer que as tendências ocorridas no Rio de Janeiro não são uma exceção em relação ao que ocorre no restante do Brasil. Simplesmente, o Rio está na vanguarda do processo de transição. O que acontece em território fluminense tende a se repetir nas demais Unidades da Federação com uma certa defasagem temporal e em ritmo um pouco mais lento. Mas a análise apresentada no texto sugere que a transição tende a se aprofundar na medida em que cresce a diversidade religiosa.

Com suas novas mensagens religiosas e com o processo de customização, as correntes pentecostais e neopentecostais conseguem difundir suas doutrinas rapidamente. Neste sentido, compreender o processo de difusão passa por conhecer os caminhos por onde se dá a conversão em suas formas concretas. O contato porta-a-porta parece ser fundamental ao processo de "fidelização dos fiéis". Neste sentido, as rodovias são um meio de viabilizar os encontros entre as pessoas e a troca de experiência entre os líderes religiosos e os fiéis que participam dos cultos e das reuniões de apoio mútuo.

Na medida em que o Rio de Janeiro, particularmente a periferia da sua Região Metropolitana, passou a ser a região com maior pluralidade religiosa e menor percentual de católicos, tornou-se foco de difusão da mensagem evangélica. O eixo da rodovia 101 que vai da Região Metropolitana do Rio de Janeiro ao Norte Fluminense e à Região Metropolitana do Espírito Santo tende a acelerar a transição religiosa, pois são duas regiões com alta presença evangélica e baixa presença relativa dos católicos. A rodovia Rio-Santos também tende a apresentar uma transição religiosa acelerada, tanto do lado dos municípios de São Paulo (como 
Ubatuba, onde os católicos estavam com menos de 50\% em 2010) quanto do lado do Rio de Janeiro (como Angra dos Reis e Paraty, onde os católicos também apresentavam taxas menores de 50\% em 2010). A rodovia Dutra tem visto os evangélicos crescerem das periferias das regiões metropolitanas do Rio de Janeiro e São Paulo, rumo ao interior. Mas a cidade de Aparecida, que fica no meio do caminho, tende a resistir e apresentar menores taxas de mudança, pois a cidade abriga a Basílica de Nossa Senhora Aparecida, Santuário Nacional da Igreja Católica.

A realidade é que as filiações cristãs estão diminuindo no Brasil e a diversidade religiosa (incluindo os sem-religião) está aumentando, enquanto tende a haver uma mudança de hegemonia com a queda do percentual de católicos e o aumento do percentual de evangélicos, em especial, os pentecostais, neopentecostais, além dos evangélicos sem filiação institucional. Estas tendências devem se aprofundar nas próximas décadas, pois as condições demográficas ajudam o crescimento dos evangélicos e o crescimento do mercado religioso tende a aumentar a pluralidade religiosa.

\section{REFERÊNCIAS}

ALMEIDA, R.; BARBOSA, R. Transição religiosa no Brasil, São Paulo: CEM/CEBRAP, 2013 (Mimeo).

ALVES, J.E.D; CORREA, S. Igualdade e desigualdade de gênero no Brasil: um panorama preliminar, 15 anos depois do Cairo. In: ABEP, Brasil, 15 anos após a Conferência do Cairo, Campinas: ABEP/UNFPA, 2009. Disponível em

<http://www.abep.org.br/usuario/GerenciaNavegacao.php?caderno_id=854\&nivel=1>. Acesso em: 10 ago. 2014.

ALVES, J.E.D; NOVELINO, M.S. A dinâmica das filiações religiosas no Rio de Janeiro: 1991-2000. Um recorte por educação, cor, geração e gênero. In PATARRA, N.; AJARA, C.; SOUTO, J. (Eds.). O Rio de Janeiro continua sendo... Rio de Janeiro: Ence/IBGE, 2006, p. 275-307. 
ALVES, J.E.D.; BARROS, L.F.W.; CAVENAGHI, S. A dinâmica das filiações religiosas no Brasil entre 2000 e 2010: diversificação e processo de mudança de hegemonia. REVER, São Paulo: PUC-SP, v. 12, p. 145-174, 2012. Disponível em

<http://revistas.pucsp.br/index.php/rever/article/view/14570 > . Acesso em: 10 ago. 2014.

ALVES, J.E.D. O Brasil em transição. Rio de Janeiro: Aparte, IE/UFRJ, 31/05/2014. Disponível em:

<http://www.ie.ufrj.br/aparte/pdfs/o_brasil_em_transicao_ence_31mai14.pdf >.Acesso em: 23 ago. 2014.

BAUMAN, Z. Amor Líquido: sobre a Fragilidade dos laços humanos. Rio de Janeiro: Jorge Zahar, 2004.

BOLA DE NEVE, Igreja Bola de Neve, 2014. Disponível em <http://www.boladeneve.com/>. Acesso em: 31 jul.2014.

CAMARGO, C., P.F. Igreja e desenvolvimento. CEBRAP, São Paulo, 1971.

CASTERLINE, J. B. Diffusion processes and fertility transition, Washington, D.C: National Academy Press, 2001.

COUTINHO, R. Z.; GOLGHER, A. B. The changing landscape of religious affiliation in Brazil between 1980 and 2010: age, period, and cohort perspectives. R. bras. Est. Pop., Rio de Janeiro: ABEP, v. 31, n.1, p. 5-23, jan./jun. 2014.

DECOL, R. Mudanca religiosa no Brasil. Uma visão demográfica. R. bras. Est. Pop., Rio de Janeiro: ABEP, v. 16, n.1/2, p. 121-137, 1999.

ELIADE, M. Dicionário das Religiões, São Paulo: Martins Fontes, 1999.

FRIGERIO, A. O paradigma da escolha racional: Mercado regulado e pluralismo religioso. Tempo Social. São Paulo: USP, v. 20, n. 2, 2008, p. 17-39.

GUERRA, L. As Influências da lógica mercadológica sobre as recentes transformações na igreja católica, Revista de Estudos da Religião, São Paulo, n. 2, 2003, p. 1-23.

LEONI, F. Superando preconceito, pastor evangélico é também drag queen. O Globo, Rio de Janeiro 18 maio 2014, Disponível em: <http://oglobo.globo.com/rio/superandopreconceito-pastor-evangelico-tambem-drag-queen-12522426>. Acesso em: 31 jul. 2014.

MACEDO, E. Edir Macedo defende legalização do aborto, Youtube, 2010. Disponível em <http://www.youtube.com/watch?v=gqCYj5HuWOQ>. Acesso em: 10 ago. 2014.

MARIANO, R. . Os neopentecostais e a teologia da prosperidade. Novos Estudos. São Paulo: CEBRAP, v. 44, n. 44, p. 24-44, 1996.

MARIANO, R. Usos e limites da teoria da escolha racional da religião, Tempo Social, São Paulo: USP, v. 20, n. 2, 2008, p. 41-66. 
MARIANO, R. Mudanças no campo religioso brasileiro no Censo 2010. Debates do NER, Porto Alegre: UFRGS, v. 14, p. 119-137, 2013.

ORO, A. P. Podem passar a sacolinha: um estudo sobre as representações do dinheiro no neopentecostalismo brasileiro. Cadernos de Antropologia, 9, UFRGS, p. 7-44, 1992.

PIERUCCI, A. F.; PRANDI, R. A realidade social das religiões no Brasil. São Paulo: Hucitec, 1996.

PRANDI, R.; SOUZA, A.R. A carismática despolitização da Igreja Católica. In: PIERUCCI, A. F.; PRANDI, R. A realidade social das religiões no Brasil. São Paulo: Hucitec, 1996.

PEW. The Global religious landscape, 2010. Washington, Dez 2012. Disponível em <http://www.pewforum.org/2012/12/18/global-religious-landscape-exec/>. Acesso em: 31 jul. 2014 .

PEW, Global Christianity: A report on the size and distribution of the World's Christian population, Pew Research Center's Forum on Religion \& Public Life, Washington, D.C, Dez, 2011. Disponível em <http://www.pewforum.org/files/2011/12/Christianityfullreport-web.pdf>. Acesso em: 31 jul. 2014.

RETHERFORD, R.; PALMORE, J. Diffusion processes affecting fertility regulation. Pp. 295-339, In: Determinants of fertility in developing countries, v. 2, R.A. BULATAO; LEE, R.D., eds. New York: Academic Press, 1983.

SILVA, F.J.C. Pentecostalismo e pós-pentecostalismo. Revista Eletrônica InterLegere, n.2, jul/dez de 2007.

STARK, R. From church-sect to religious economies. In: HAMMOND, P. E. (ed.), The sacred in a post-secular age. Berkeley, University of California Press, 1985.

WEBER, M. A ética protestante e o espírito do capitalismo, São Paulo: Pioneira, 1967. 